\title{
A SLIPPERY SLOPE
}

\section{THE RISE AND FALL OF THE DOMESTIC SOAP OPERA IN ITALIAN PUBLICAND COMMERCIAL TELEVISION}

Daniela Cardini

Dipartimento di Comunicazione, Arti e Media

Università IULM

Via Carlo Bo, 8

20143 Milano

Italy

daniela.cardini@iulm.it

\begin{abstract}
Prior to the mid-nineties, Italian television did not produce any soap operas. Daytime serials were imported mainly from the USA.

Unexpectedly, the most commercial television genre was produced for the first time by the public service broadcaster: Un posto al sole was aired by RAI in 1996. The commercial competitor Mediaset immediately responded with Vivere in 1998 and CentoVetrine in 2001. Un posto al sole still airs today, while both Mediaset's soaps were cancelled.
\end{abstract}

The paper focuses on the rise and fall of domestic long-running daytime serials, on the different choices taken by the two competitors and on the perspectives opened up by the genre on Italian TV schedules.

Keywords: soap opera, Italian television, daytime drama, television production, commercial television.

\section{Introduction}

Unlike the majority of continental Europe, until the mid-Nineties, there was no local production of soap operas in Italian television. Instead, daytime serials were imported and dubbed, mainly from the USA. The public broadcasting company, RAI, considered the genre as being of poor cultural level, unsuitable for the mission of public service television. But the production of the genre was not a goal for the newly born commercial television, Mediaset, either: it was more profitable to import soap operas from the United States than to produce them in Italy.

Unexpectedly, in 1996, RAI itself produced and aired the first Italian soap opera, Un posto al sole. Its huge success quickly convinced Mediaset to enter a profitable market. In less than three years, from 1998 to 2001 , two new soaps were produced: Vivere and CentoVetrine. 
The story of the domestic soap opera genre is a great example when analyzing the heated debate in the industrial, political and cultural aspects of Italian television, where the commercial broadcaster played (and still plays) a decisive role.

The article will focus on the reasons of the late rise and of the present crisis of the domestic soap opera in Italian television. The socio-cultural frame where the Italian soapscape was born and the political features which gave birth to commercial broadcasting in the eighties will be taken into account. The cultural and industrial reasons behind the production of the first domestic soap opera, Un posto al sole, will be briefly described, followed by the reaction of the commercial broadcaster. The strategy of commercial television will be analysed by taking into consideration the narrative features and the scheduling techniques that distinguish the two competitors. In conclusion, the crisis of the domestic commercial production will be considered, together with a quick glance at the new perspectives in the field.

\section{The Beginning of Italian Commercial Television (1980-1995)}

In the early eighties, the newly born Italian holding company, Fininvest (owned by Silvio Berlusconi), brought the monopoly of the public service television network, RAI, to an end. Having started his activities in the real estate market in the sixties, by the mid-seventies, Berlusconi's interests turned to the media market and television became a pivotal asset in the Italian-tycoon's group. From 1980 to 1984, Fininvest succeeded in buying out three television channels: Canale 5, Italia Uno, and Retequattro. Up until then, the monopoly of RAI was founded on its three channels (Raiuno, founded in 1954; Raidue, 1961; and Raitre, 1979) and on the pedagogic mission upon which John Reith's BBC was built in the fifties: to educate, to inform, and to entertain. ${ }^{1}$

Fininvest brought an aggressive marketing and advertising strategy to Italian television, whose content and audience habits were deeply transformed over the next decade. The particular Italian political climate of the eighties contributed to the birth of what was called a television "duopoly". This peculiar definition means that not only did RAI and Fininvest ${ }^{2}$ have the same economic, political, and social relevance (both of them owned three channels, both had political protection, and both were financed through advertising, even if RAI was, and still is, also financed through taxes), but also that through the eighties and nineties they harshly fought each other as competitors focused on providing the same types of content and genres, instead of developing their uniqueness.

This attitude is particularly clear in the development of domestically produced long-running daytime serials. Prior to the mid-nineties, original soap operas were totally absent from Italian television schedules. ${ }^{3}$ In the United States and in other European countries, such as the UK and Germany, the industrial production of this genre had been routine for decades, ${ }^{4}$ while in Italy, the reputation of the genre suffered from a deep-rooted cultural prejudice, based on its poor

1 Aldo Grasso, Storia della televisione italiana, Garzanti, 2000; Franco Monteleone, Storia della radio e della televisione in Italia. Un secolo di costume, società e politica, Marsilio, 2001; Enrico Menduni, Televisione e società italiana 1975-2000, Bompiani, 2002; Peppino Ortoleva, Mediastoria. Mezzi di comunicazione e cambiamento sociale nel mondo contemporaneo, II Saggiatore, 2002.

2 In 1995, all of the activities linked to the television market were separated from the holding company, Fininvest, and were grouped under the label "Mediaset". For the sake of simplicity, in the following pages we will use its current name even when some of its described activities took place prior to 1995 .

3 Daniela Cardini, La lunga serialità televisiva. Origini e modelli, Carocci, 2004.

4 See for instance the German soap, Lindenstraße (Das Erste, 1985-present), inspired by the British forerunner Coronation Street (ITV, 1960-present), and the other British milestone, EastEnders (BBC One, 1985-present). In the United States and in the UK, the academic debate on the serial form became particularly animated in the early eighties; it focused both on the features of the genre and on case studies of some domestic shows: Robert C. Allen, Speaking of Soap Operas, University of North Carolina Press, 1985; Id., ed., To be Continued... Soap Operas around the World, Routledge, 1995; David Buckingham, Public Secrets: EastEnders and its Audience, BFI Publishing, 1987; Dorothy Hobson, Crossroads: The Drama of a Soap Opera, Methuen, 1982; Richard Dyer et al., Coronation Street, BFI Publishing, 1981; Muriel Cantor and Suzanne Pingree, The Soap Opera, Sage, 1983. 
aesthetic values and trivial content. ${ }^{5}$ But the harshness and rapidity of the competition between private and public television models caused a radical and quick turn in the attitudes of Italian television experts. In the new competitive scenario, both RAI and Mediaset realized how profitable that genre could be, and consequently they understood the need to overcome any cultural bias: the idea that soap operas are cheaper to produce than other genres (such as drama or prime time entertainment) and they can build a large and faithful audience. ${ }^{6}$ For this reason, they are a core business of commercial television broadcasting. So, in less than five years, from 1996 to 2001, three new original soaps were created: Un posto al sole (RAI, 1996), Vivere (Mediaset, 1998), and CentoVetrine (Mediaset, 2001). An Italian approach to the soap opera was born, ${ }^{7}$ whose characteristics show the differences in the two competitors' strategies and the uniqueness of the Italian television system at large.

Surprisingly, in spite of its deep-rooted cultural bias, it was the public service network, RAI, that started the production of the most commercial TV genre in 1996. Mediaset immediately responded by producing two soaps in less than three years and by building a new production centre near the city of Turin that was totally devoted to the production of longrunning daytime serials. ${ }^{8}$

After two decades, the Italian "soapscape" has completely changed. Only RAl's show, Un posto al sole, is still on the air, while both Mediaset soaps were cancelled (Vivere in 2008, CentoVetrine in 2015). But the relevance of the genre for the commercial network is attested by the recent, unpredictable success of imported daytime serials, such as the Spanish serial, El Secreto de Puente Viejo (Canale 5, 2013-present) or the German serial, Sturm der Liebe (Canale 5-Retequattro 2006-present), as we will see in the next section.

\section{The Competition on Daytime Serial Dramas}

From its birth in the early fifties until the seventies, RAl's serial drama production was mainly focused on the "sceneggiato" genre, that is, the television adaptation of classic literary masterpieces (e.g. Dickens' David Copperfield, Manzoni's I Promessi sposi and Tolstoy's War and Peace). In the difficult environment of post-war Italy, RAI undertook a pedagogic mission to popularize domestic and international classic novels to a vast and poorly educated audience. ${ }^{9}$

In parallel with the production of this expensive genre, a cheaper domestic format was developed, the so-called miniseries (from 2 to 6 or 8 episodes), whose narratives mainly dealt with national themes (family and love stories, crime stories, biographies of famous historic Italian characters, and so on). ${ }^{10}$ Before the end of the seventies, very few imported serials were put on RAl's schedules ${ }^{11}$. The advent of the commercial television broadcaster in 1980 radically

5 The Italian academic debate on the need for serial form in domestic television started in the mid-eighties, but the production of original soap operas began more than ten years later. Some classic references are: Alberto Abruzzese, ed, Ai confini della serialità, Società Editrice Napoletana, 1984; Francesco Casetti, ed, L'immagine al plurale. Serialità e ripetizione nel cinema e nella televisione, Marsilio, 1984; Alessandro Silj, ed, A est di Dallas. Telefilm USA e europei a confronto, VQPT RAI-Eri, 1987.

6 Charlotte Brunsdon, The Feminist, the Housewife and the Soap Opera, Oxford University Press, 2000; Christine Geraghty, Women and Soap Opera: A Study of Prime Time Soaps, Polity Press, 1991; Sonia Livingstone, Making Sense of Television, Routledge, 1998; Tamar Liebes and Sonia Livingstone, "European Soap Operas: The Diversification of a Genre", European Journal of Communication, 13, 2, $1998,147-80$.

7 Daniela Cardini and Saveria Capecchi, "Un posto al sole. Produzione, contenuti e pubblico della prima soap opera italiana”, Problemi dell'informazione, 2, June 1998, 245-267; Elisa Giomi, Il piacere di "Vivere”. Analisi di una soap di successo e del suo pubblico, Bulzoni, 2004; Milly Buonanno, La fiction italiana, Laterza, 2012; Daniela Cardini, "Looking for A Place in the Sun? The Italian Way to the Soap Opera", in Diana I. Rios, Mari Castaneda, eds, Soap Operas and Telenovelas in the Digital Age. Global Industries and New Audiences, Peter Lang 2011, pp. 111-128, Luca Barra, "L'Italia in vetrina. Spazi e modelli produttivi della soap opera televisiva", Bianco e Nero, 578, 2014, 55-65.

8 Daniela Cardini, La lunga serialità televisiva. Origini e modelli, Carocci, 2004.

9 Aldo Grasso and Massimo Scaglioni, Che cos'è la televisione. Il piccolo schermo fra cultural e società: i generi, l'industria, il pubblico, Garzanti, 2003; Oreste De Fornari, Teleromanza. Storia indiscreta dello sceneggiato tv, Mondadori, 1990.

10 Milly Buonanno, La fiction italiana, Laterza, 2012.

11 See for instance the miniseries: Roots (ABC/Raidue 1977), Happy Days (ABC/Raiuno 1977), Eight is enough (ABC/Raiuno 1978), Little House in the Prairie (NBC/Raiuno 1977). 
changed this situation. Mediaset's strategy was mainly focused on the purchase of American serials, which were cheaper and more profitable to buy than they cost to produce ${ }^{12}$. The scheduling of American serials was planned using careful marketing strategies, which until then were totally unknown by RAI. TV programs became "events", which were advertised and sold to the audience long before their actual scheduling.

The clash of two different cultures in the field of seriality became clear in the case of Dallas, the famous US prime time soap opera produced by the American network, CBS. ${ }^{13}$

Video 1. The opening credits of the first season of Dallas, 1978. Please visit the online version of the article to watch this video.

RAI bought Dallas from CBS in 1978 - when RAI still had a monopoly on Italian television. In spite of its huge popularity all over the world, RAI was still unaware of the relevance of the serial form in the contemporary international television market, and considered Dallas to be nothing more than an exotic outsider. Up until 1981, the show remained unaired. In 1981, forced by the competition with the newly-born commercial network which was introducing in the Italian television context the genre of the imported serial, RAI decided to schedule Dallas, but it totally ignored its correct serial flow: the episodes of the first and of the second season were randomly aired, and the audience was obviously confused by the show. At the end of the same year, Mediaset bought the unsuccessful show from RAl. Canale 5, one of the three channels owned by Berlusconi, scheduled the first and second season in the correct chronological order. Its airing was preceded by a careful advertising campaign based on teasers, which were a totally unknown advertising technique on Italian television. For the first time, hype was created for a television show, and the success was huge. ${ }^{14}$

From then on, Hollywood movies and imported serials became a conspicuous part of Mediaset's daily schedules, together with the first daytime soaps like General Hospital (Canale 5 1982-1989, then Retequattro 1989-1993), or Guiding Light (Canale 5, 1982-1988, then Retequattro, 1988-2012), and Latin-American telenovelas. Telenovelas were totally unknown by the Italian audience, but the genre was very cheap in international markets and it soon became a cornerstone in Mediaset's new daytime schedule: the huge success of Escrava Isaura (Retequattro, 1982) and Dancin' Days (Retequattro, 1982) started a flood of Brazilian and Mexican productions in the commercial daily schedules.

Ten years after the shock of Dallas, another imported daytime serial was at the centre of a harsh fight between the two competing broadcasters. In 1990, RAI decided to enter the market of imported daytime serials through the acquisition of an American soap opera produced by CBS, The Bold and the Beautiful, which during the same year debuted on RAl's second channel, Raidue, where it scored unexpectedly high ratings and where its huge success would continue for four years.

However, in 1994, the television rights for the show expired. RAI did not renew its options and Berlusconi fought to buy the show: in front of his higher economic offer to the American network, CBS, RAI was forced to back down ${ }^{15}$.

Video 2. The opening credits of the first season of The Bold and the Beautiful in Italy, 1990. Please visit the online version of the article to watch this video.

12 See for instance: Magnum P.I. (CBS/Canale 5 1982), Charlie's Angels (ABC/Retequattro 1980), The A-Team (NBC/Retequattro1984).

13 Dallas is a milestone in the international academic debate on seriality in the eighties and nineties: len Ang, Watching "Dallas". Soap Opera and the Melodramatic Imagination, Methuen, 1985; Florence Dupont, Homère et "Dallas": Introduction à une critique anthropologique, Hachette, 1991; Tamar Liebes and Elihu Katz, The Export of Meaning: Cross-cultural Readings of "Dallas", Polity Press, 1990.

14 Alessandro Silj, ed, A est di Dallas. Telefilm USA e europei a confronto, VQPT RAI-Eri, 1987.

15 Paola Colaiacomo, Tutto questo è Beautiful. Forme narrative della fine del millennio, Luca Sossella Editore, 1999; Orsola Mattioli, "Beautiful, o delle passioni verbalizzate,", in Omar Calabrese et al., eds, Le passioni nel serial tv, RAI-Eri, 1994, pp. 67-84. 
On April 4th, 1990, The Bold and the Beautiful was aired by Canale 5, which made it the cornerstone of its daytime slot, and still boasts an average daily audience of 6 million people. From then on, the soap opera genre in Italy has been defined by its slow narrative rhythm, its complicated and unrealistic love relationships, and its handsome "tabloid-style" characters. Similar to what happened with Dallas, once again Mediaset "stole" a successful TV show from RAl's schedules and turned it into gold. After that "lesson" in the television market arena, it was evident that seriality was a crucial asset, which could not be underestimated any longer.

\section{The First Italian Soap Opera: Un posto al sole (RAI, 1996 -Present)}

In the mid-nineties, Mediaset and RAI did not have either the necessary technical skills or the industrial infrastructure to produce an original soap opera. Unlike any other television serial drama, soaps must simultaneously be written, filmed and post-produced, essentially as an industrial assembly line model; just like its narrative structure, its inprogress production routines are potentially never-ending too. Storyliners must take into account the need for inserting commercial breaks, which are an essential part of the profitability of the show. The shows can be re-scheduled and rerun and they can be sold on international markets. These are reasons why soaps are an asset for a television network, despite their bad reputation in the "high-brow" television scholarship.

Italian television had no tradition in the industrial production of this genre: RAl preferred the mini-series format and Mediaset was more focused on buying serial dramas than on producing them. But the need for an original serial drama could not be ignored any longer, and not only for economic reasons. In the nineties, the global-local theme was the main theoretical and cultural issue in international media and television studies: the need for "national drama", ${ }^{16}$ that is, a domestic daily serial narrative which could give voice to local cultural and social needs and identities, could no longer be underestimated. In this context, the two Italian broadcasters had to face the difficult choice of whether to adopt a more profitable production model upon which the much needed "soap opera factory" could be based. Two alternatives were at stake: the first one was the American model, epitomized by The Bold and the Beautiful, based on a slow narrative rhythm and focused on love stories, which take place in luxury interiors and stereotyped locations and which involve many handsome and good-looking characters who live - and occasionally work - in an aspirational luxurious world. The second alternative model, the British serial drama represented by Coronation Street (ITV, 1960-present) and EastEnders (BBC One, 1985-present), was completely unknown by the Italian audience: characters and locations are represented in a realistic way; communities are more important than couples, and storylines based on friendship or working relationships are often more relevant than love stories. In addition, individual and social problems such as drugs, unemployment, and illness play a major role in the narratives.

Video 3. The first episode of EastEnders, the most popular British Soap opera, 1985. Please visit the online version of the article to watch this video.

Unexpectedly, it was the public service broadcaster who started the game of producing the most commercial of television genres. Moreover, instead of choosing the successful US soap opera model of The Bold and the Beautiful, RAI followed the British serial drama production model. ${ }^{17}$ In 1996, RAl signed a joint venture with an Australian-based television company, Grundy Production, which owned the rights to a successful Australian soap opera, Neighbours, a format which at that time had already been purchased by 25 countries $^{18}$. This choice was risky. Neighbours was based

16 Horace Newcomb, Television. The Critical View, 5th ed., Oxford University Press, 1994; Sonia Livingstone, Making Sense of Television, Routledge, 1998; Robert Allen, Speaking of Soap Operas, University of North Carolina Press, 1985; Robert C. Allen, ed, To be Continued... Soap Operas around the World, Routledge, 1995.

17 Daniela Cardini and Saveria Capecchi, "Un posto al sole. Produzione, contenuti e pubblico della prima soap opera italiana”, Problemi dell'informazione, 2, June 1998, pp. 245-267.

18 The Australian soap opera genre is based on the British model. 
upon realism and community relationships rather than upon sentimental issues, so its narrative structure was very far from the habits of the Italian audience.

Video 4. In the Australian soap Neighbours, a sixteen-year-old Kylie Minogue (as Charlene Robinson) debuted on April $17^{\text {th }}$, 1986. Please visit the online version of the article to watch this video.

Another risky issue was that Neighbours was a format. In the nineties, imported and adapted formats were not so common in Italian schedules. It would still take some years for Big Brother and the reality show genre to conquer Italian television. In particular, serial drama was traditionally considered as the most difficult genre to be formatted. ${ }^{19}$ But RAI needed to learn how to create such a complex show from scratch; therefore, the Italian broadcaster bought its technical skills in producing a long-running serial drama from Grundy. Italian storyliners were not used to coping with many characters and storylines at the same time and so they had to learn from Australian headwriters how to manage long-running stories involving more than twenty main characters on a daily basis. Italian actors, who mostly had experience from theatre or movies, were trained by Australian teachers on how to play multiple scenes per day, as required by the soap opera genre. Italian directors were trained in how to film so many actors at a time given a very short amount of time. Every single production step had to be understood, studied, learned and adapted to local needs, in a constant, delicate and often controversial mediation process.

The debut of the show, on October 21, 1996 on Raitre, was predictably difficult. The Italian audience's reaction was lukewarm. In the first season, inexperienced actors and authors made many mistakes. Moreover, the show was scheduled in a late afternoon slot $(6.30 \mathrm{pm})$ - which was unsuitable for a traditionally daytime genre - and afterwards, it was shifted to the even more difficult access prime time slot $(8.30 \mathrm{pm})$.

Happily, RAI seemed to have learned how to deal with seriality: in spite of its laboured first season, the show was allowed the time to build its audience. In the following months it was carefully re-written; the day-by-day training improved actors' and authors' performances, and, little by little, the first Italian soap opera became popular and loved by a faithful audience 20 .

In contrast with the glossy style of The Bold and the Beautiful, which is based on never-ending love conversations between two handsome and forever young-looking characters in their luxury villas in a glossy and unreal Los Angeles, the realistic stories of Un posto al sole take place not only in living rooms and kitchens, but also in pubs, shops, and workplaces. Characters are real-looking people of all ages. The fast-paced narrative is focused not only on love affairs, marriages and friendship storylines, but also on social and cultural themes such as alcoholism, abortion, divorce, crime, and drugs. The streets and squares of Naples, the sunny Mediterranean city where the action takes place, are present in each episode. The main location is a beautiful three-storey "villa" in the Posillipo gulf, where most of the characters live; the atmosphere is sunny and warm, and a bit of humour is present in each episode.

Video 5. A video montage of the first seasons of Un posto al sole, from its debut in 1996 until 2001. Please visit the online version of the article to watch this video.

19 Justin Malbon and Albert Moran, Understanding the Global TV Format, Intellect, 2006; Albert Moran, ed, TV Formats Worldwide: Localizing Global Programs, Intellect, 2009; John Ellis, Andrea Esser and J. F. Lozano, "Editorial: TV Formats and Format Research: theory, methodology, history and new developments", VIEW: Journal of European Television History and Culture, 5, 9, 2016, pp. 1-5.

20 On its debut in the 6:30 pm slot, the soap scored just over a million viewers. After the move to $8: 30$ pm, its success grew steadily, reaching $15 \%$ points with more than three million viewers. At present, the average score is about $2,700,000$ viewers with a share between $9 \%$ and $10 \%$, which is a very good rate for a time slot where the news and very popular access primetime game shows are scheduled. Source: https://it.wikipedia.org/wiki/ Un_posto_al_sole 


\section{Mediaset and the Soap Opera Factory: Vivere (1998-2007) and CentoVetrine (2001-2015)}

One year after Un posto al sole premiered on Raitre, the third channel of the public TV service, Mediaset recruited half of its production crew (authors, directors, headwriters, and editors) with the aim of producing its own long-running daytime serial. Creative and writing work on Vivere, Canale 5's first soap opera, began in 1998 and the first episode premiered on March 1, 1999.

Video 6. The opening titles of the first season of Vivere, 1998. Please visit the online version of the article to watch this video.

Mediaset rapidly overcame the delay in the production of the soap opera genre through careful scheduling and marketing techniques, such as hammocking (to place a new program between two consolidated shows) and the leadin (to place a new program with the same mood after a very successful show). ${ }^{21}$ Vivere was scheduled at $2.15 \mathrm{pm}$, after The Bold and the Beautiful, which scored a daily average of 5 million viewers, and before the popular talk show Uomini e Donne ("Men and Women"), which focused on the love affairs of ordinary people.

As far as the overall tone of the new soap was concerned, the authors chose a balance between the exotic love stories of The Bold and The Beautiful and the Mediterranean realistic flavour of Un posto al sole. Unlike the sunny and Mediterranean mood of its competitor, Vivere is located in Como, a town on the lakeside in Northern Italy, whose romantic but foggy and sometimes melancholic atmosphere is quite distant from the warm and cheerful Neapolitan mood portrayed in the other shows. The lake was the most suitable setting to give stories and relationships a dark edge, with the aim of emphasizing crime and mystery storylines. Instead of the light entertaining flavour of some Neapolitan storylines, in Vivere, the Northern mood gives more relevance to work as a narrative drive. Many storylines take place in working places: meeting rooms, shops, and restaurants. There is no irony in Vivere; besides love and friendship, its narrative focus is on mystery and crime stories, which mirror the gloomy atmosphere of the lake. In a similitude with the landscape, characters hide many secrets behind their quiet appearance. The typical comedy flavour of Un posto al sole is replaced by a much gloomier mood.

In long-running daytime serials, the production unit is the "block", not the single episode as it usually is in prime time dramas. The block is the sum of the five episodes, which are aired over one week. The production routine is divided into three main phases: the pre-production phase (scripts and dialogues), the production phase (shooting), and the post-production phase (audio and video mix and correction). In Un posto al sole, each block takes four weeks to complete the pre-production phase, four weeks for the shooting phase, and two weeks for the editing phase.

The three phases are simultaneously involved, but each of them is engaged in a different block production, in a different phase of the process. To sum up a very complex routine, we can say that in the "assembly line" of Un posto al sole, ten blocks are simultaneously in production in the same week, in a never-ending process. ${ }^{22}$

In the production routine of Vivere, two more weeks were added, with the aim to achieve a slower narrative rhythm which was meant to not differ too much from the style of The Bold and the Beautiful. Compared to the faster pace of Un posto al sole, the narratives of the Mediaset soap are focused on dialogues rather than on action, with the aim to create a homogeneous "tone of voice" in the daytime slot, bringing the female viewers from the exotic melodrama of The Bold and the Beautiful, to the gloomy love stories of Vivere, and finally to the daily talks and gossip of Uomini e Donne. 
Thanks to its carefully planned marketing and advertising campaign, Vivere was a huge success from the very beginning. From $1.30 \mathrm{pm}$ to $3.30 \mathrm{pm}$, a large feminine audience was easily led from their favourite American soap to the new Italian one, and finally "talked love" during their favourite daily "pink" talk show.

Audience scores were so good that Mediaset decided to begin a new soap opera project. The relevance of the soap opera for a commercial network was so clear as to convince Mediaset to create a new production facility. In 2001, the all-new "soap factory" Telecittà was built in San Giorgio Canavese, a small town in the Turin area, and the CentoVetrine project could be started.

With the aim of a more profitable investment plan, Mediaset established a totally new production routine that pushed the assembly line model forward. Unlike Un posto al sole and Vivere, whose goals were fixed on five episodes per week, the faster production routine of CentoVetrine had to produce six episodes per week. To achieve this ambitious goal, each block would need to be written, filmed and edited in four weeks - instead of five. Thanks to the new facility, actors, authors, directors, and technicians all lived together in Telecittà, which controlled and reduced wasted time. As costly and time-consuming shootings on location needed to be reduced to a minimum, the aesthetic quality became essential: direction, acting, light design, and editing needed to be of higher quality in comparison with the other soaps. As a consequence, it was necessary to double both the production and the writing teams.

The stories of CentoVetrine took place in a shopping mall in Turin. Due to the production needs, the shootings on location were reduced to a minimum, and the role of the city was less important compared to the romantic Como lake in Vivere and the sunny Naples in Un posto al sole. The action mostly occurred in interior locations; therefore, the relations in working places were the main focus of the storylines. Shopkeepers, white-collar workers, but also lawyers, physicians, and freelancers formed the social set of the love and friendship stories of the new Mediaset soap. With the aim of launching the new soap in the most profitable way possible, CentoVetrine was scheduled at $2 \mathrm{pm}$, starting from January 8th, 2001. It took the place of Vivere, which was shifted to the less popular time slot of $12.30 \mathrm{am}$. As we will see in the next pages, this choice had significant consequences for its ratings.

Video 7 . CentoVetrine, the first episode (January $\left.8^{\text {th }}, 2001\right)$. Please visit the online version of the article to watch this video.

\section{RAI's (Unsuccessul) Response: Agrodolce ( $2008-2009)$}

In the meantime, Un posto al sole was regularly broadcast at $8.30 \mathrm{pm}$ on Raitre, scoring positive and consistent ratings on a daily basis. Almost ten years after its debut, the same team who produced the Neapolitan soap opera started another project by RAI. A new long daily serial, Agrodolce, was broadcast on Raitre starting on September 20th, 2008. Like Mediaset did with the creation of Telecittà, RAI also wanted to build its own industrial facility, where soap operas could be produced. However, the project was not successful and after only one year it was cancelled.

The project was very ambitious. It was meant to reaffirm the skills and competence of RAl in producing soap operas against its main competitor. It was also meant to establish a television factory in Sicily, a beautiful but poor region in Southern Italy, where RAI could fulfil its public service mission by creating new jobs. The choice of Sicily as the location for the new TV industry was very controversial. In this region, it is usually difficult to establish economic businesses for political and cultural reasons. But in spite of many obstacles, a "television town" was created in Termini Imerese, a small centre near Palermo: 2,000 square feet studios, and high technology facilities - employing, for instance, the HDTV technique.

Furthermore, the writing team wanted to establish a unique mood for the show, inspired by the "great Italian popular novel," drawing on the themes of national literary production and traditional neorealism of Italian film, thus setting itself clearly aside from the stereotypes of American soap opera - deep emotions, but also social conflicts, (neo)realism and a strong Italian flavour, both in the characters and in its locations. As a consequence, the narratives of the new soap 
opera were characterized by many scenes on location, which showed the beautiful natural sets of the Mediterranean isle. Seven families from different economic and cultural backgrounds, from wealthy aristocrats to poor workingclass people, faced each other in real-life storylines, and involved issues such as the struggle against the mafia, immigration, unemployment, health and education.

The project was financed through a joint venture between RAI and Sicily's regional government, by drawing on European Union funds. After a long preparatory phase, the first season of 230 episodes of the Sicilian soap opera was completed. The show debuted on September 8th, 2008. With the aim of creating an "Italian soap opera strip", Agrodolce was scheduled just before Un posto al sole, at $8.10 \mathrm{pm}$. But the new soap had to face two giants who occupied this slot: Raiuno and Canale 5's evening news, which are broadcast from 8 to 8.30 every evening. In the first weeks, the show scored fairly poor ratings. A light improvement was registered after the first months, but not enough to be confirmed for a second season. The European grant was not renewed and the show was cancelled after the 230th episode, on July 24th, 2009.

Video 8. Agrodolce, the latest episode (July $\left.24^{\text {th }}, 2009\right)$. Please visit the online version of the article to watch this video.

\section{The Rise of Reality Shows and the Decline of the Italian Soap Opera}

The year 2000 marked a turning point in the history of Italian television: Big Brother's first edition cleared the way for the long-lasting success of the reality show genre.

Italian schedules were flooded by the lives of ordinary people, whose love stories, quarrels and emotions were greedily followed by viewers on a daily basis, as they were "real" soap operas. In comparison with soaps, reality shows can be less expensive to produce, they can be scheduled both in daytime and in prime time and they can score higher rates - and higher advertising revenues.

For commercial networks, reality shows proved to be a gold mine. Mediaset immediately devoted most of its financial and creative resources to this profitable genre, leaving the soap opera production aside. Furthermore, reality shows are formats: the revolution of Big Brother introduced this unknown word into the Italian television culture. It is far less risky to localize an international format than to produce an original show: starting in the year 2000, this "law" ruled the international television market - and still does ${ }^{23}$.

During the same period, a new competitor entered the television arena: in 2003, Sky Italia debuted and its aggressive and innovative marketing strategy deeply worried Mediaset. In fact, the competition between the two was harsh from the very beginning: Sky succeeded in buying the broadcasting rights for football matches and imported the new, fashionable cinematic TV series from the United States to Italy. ${ }^{24} \mathrm{~A}$ richer, younger, more cultivated audience was more and more attracted by the new style and programming of satellite television - and investors were too.

After the failure of Agrodolce, RAI decided not to invest in new soap productions any more; the ratings of Un posto al sole were positive and consistent. Mediaset privileged the more profitable reality show genre and the localization of foreign formats, which were more suitable to the strategies of commercial television. Producing soap operas was no longer a priority. In 2001, after being unexpectedly shifted to the new 12.30 am scheduling slot - before Canale 5's

23 Italian and international references and studies on Big Brother and the rise of the reality show in international televisions are numerous. See, for instance: Aldo Grasso, "Il dissodatore appassionato", In Id., ed., Storie e culture della televisione italiana, Mondadori, 2013, pp. 5-25; Paolo Mosca, Reality. Dal Grande Fratello all'lsola dei famosi, Bompiani, 2013; Ernst Mathijs and Janet Jones, Big Brother International: Format, Critics and

Publics, Columbia University Press, 2005.

24 Jason Mittell, Complex TV: The Poetics of Contemporary Television Storytelling, New York University Press, 2015. 
mid-day news -, Vivere experienced a predictable decline in ratings, but after a while it regained a good share, which confirmed how deep-rooted its fans' affection was. In 2007, some ups and downs in ratings convinced Mediaset to reschedule the soap once again to a new slot, $3.30 \mathrm{pm}$, where it still scored very good ratings.

Yet, by the end of that year, budget cuts forced a total restyling of the show. Many actors left the production and their characters were abruptly cancelled, without any explanations given to fans. New characters and new places were introduced and, again, the soap was re-scheduled to the 12.30 am time slot. Maybe predictably, rates were poorer than expected, so Mediaset decided to stop the production of the show and fired more than 200 people, causing strong protests among actors and fans, which nevertheless remained unheard. Retequattro, the "oldest" channel of the network, which traditionally scheduled Latin American telenovelas, broadcast the last season of the show. In spite of this, ratings were still quite good, but it could not hamper the end of this much loved show.

The "soap opera factory," which was supposed to be one of Mediaset's production glories, became a single program affair devoted to the sole survivor, CentoVetrine. CentoVetrine had a longer life than Vivere (from 2001 to 2015), but an even more turbulent story. Ten years after its debut, tensions between the production company and the broadcaster begun, due to rumours of budget cuts that alarmed both the crew and the fans. The ups and downs of this struggle went on for more than three years, during which the soap was re-scheduled, stopped and restarted, until its definite stop in 2015, which resulted in the definitive disappearance of Telecittà's production revenues.

The closure of the Italian soap opera factory reflects the global crisis of the genre.

As Henry Jenkins discussed in a four-part post on his online blog, ${ }^{25}$ the international decline of the soap opera can be explained by different factors. In the last few years, television strategies have profoundly changed: soap operas need time and patience to build their faithful audiences, but because of the bad reputation of the genre, this attitude is not socially rewarded. Also, from an economic point of view, television strategies are nowadays based on the need for immediate results. Recent American TV series appeal to audiences with a taste for complex and dense narrative, which privilege action instead of dialogues, while the slow narrative rhythm of soap operas has remained unchanged from its historic beginnings, when Irna Phillips created The Guiding Light (1937-2009) and many other successful soaps. ${ }^{26}$

Thus, in the last few years, the soap opera production has underwent a serious international decline; but it has not totally disappeared. As Robert Allen said, the long seriality matches the cultural need for daily storytelling, and it has moulded itself on the mediascape and its technological changes. Therefore, even though the original soap opera is not produced any more, the need for the genre is still alive in the audience, as Mediaset experienced from 2013. During the stop-and-go scheduling of CentoVetrine, in the summer of 2013, Mediaset broadcast a Spanish soap opera, El Secreto de Puente Viejo, with the aim of temporarily replacing the domestic soap with a cheap and profitable imported show. It was an explosive and unexpected success.

Video 9. The first Italian trailer of El Secreto de Puente Viejo ("II Segreto", Canale 5, 2013-). Please visit the online version of the article to watch this video.

\section{Conclusions: New Strategies, New Genres - the Italian Success of a Spanish Soap Opera}

In the last decade, unlike Italy and the US, Spanish television invested a huge amount of money in the production of original soap operas, which - in addiction - could also be suitable for foreign markets: low costs and high revenues.

25 Henry Jenkins, "The Survival of Soap Opera (part one):The State of the American Soap", December 6, 2010, http://henryjenkins.org/2010/12/ the_survival_of_soap_opera_par.html

26 Irna Phillips (1901-1973) is the most famous American soap opera author 
Following the big success of the German soap, Sturm und Liebe (Tempesta d'amore, Das Erste/Retequattro 2006-present), Mediaset turned to the emerging Spanish market, and bought El Secreto de Puente Viejo from the Spanish broadcaster, Antena 3, for less than 5,000 euros per episode. It scored a surprising 2.5 million rating, which grew constantly until reaching the present 4 million viewers per episode.

The success of a Spanish drama is not an exception in the Italian television market. In the last few years, many successful Spanish prime time series, such as Médico de familia (Telecinco, 1995-1999; Un medico in famiglia, Raiuno, 1998-present), Los Serrano (Telecinco, 2003-2008; I Cesaroni, Canale 5-Retequattro, 2006-2014), Polseres Vermelles (TV3-Antena 3, 2011-2013; Braccialetti Rossi, Raiuno, 2014-present), have been adapted for Italian audiences. Spanish television invested in the production of soap operas to replace the successful Latin American telenovelas with original daytime serials. The traditional narrative structure of the telenovela was still appreciated, but the Spanish audience asked for a renewal in storylines and characterization, more focused on family relationships than on the traditional melodramatic love stories ${ }^{27}$.

El Secreto de Puente Viejo is the result of a clever recipe: the long dialogues which are typical of the telenovela are mixed with the two main traditions of daytime serial storytelling: the endlessness of the US soap opera, and the relevance of the realistic issues, which is typical of British serial dramas. Moreover, El Secreto de Puente Viejo is a period drama. The action takes place in a recent past, which allows for a sort of "distant identification" with female characters by female viewers, who empathize with the difficulties of women's life when their social rights were still unattended. ${ }^{28}$

The unexpectedly huge success of El Secreto de Puente Viejo answered the audience's demand for daytime drama without the risks that come with the expensive investments that are associated with original productions. This strategy echoes the origins of Italian commercial television back in the eighties, when Mediaset strictly followed the golden rule of television marketing: "to import a show is more profitable than to produce it". In the near future, the market and the audience's reactions will confirm whether this strategy is still a winning one - or not.

\section{Bi o graphy}

Daniela Cardini is assistant professor at IULM University in Milan. Her research focuses on the development of the serial form in the media, particularly in television narratives and production. On this topic she has published several contributions, among which the book La lunga serialità televisiva. Origini e modelli (Carocci Roma 2004), and several essays in journals and edited books such as: 'Il telecinefilo. II nuovo spettatore della Grande serialità televisiva' in Between, 2014; 'Serial contradictions. The Italian debate on television series' in SERIES - International Journal of Television Narratives, 2016; 'Le serie tv sono la nuova soap opera? Luci ed ombre della serialità televisiva in Italia' in Between, 2016.

27 Algerino Marroncelli, "Non chiamateli culebrones. Storia, tecnica e successo delle serie quotidiane spagnole", in LINK-Idee per la televisione, Telenovela Oggi, RTI, 20, 2016, pp. 87-97.

28 Teresa Ciabatti, "Il segreto del Segreto", LINK-Idee per la televisione, Telenovela Oggi, RTI, 20, 2016, pp. 98-105. 